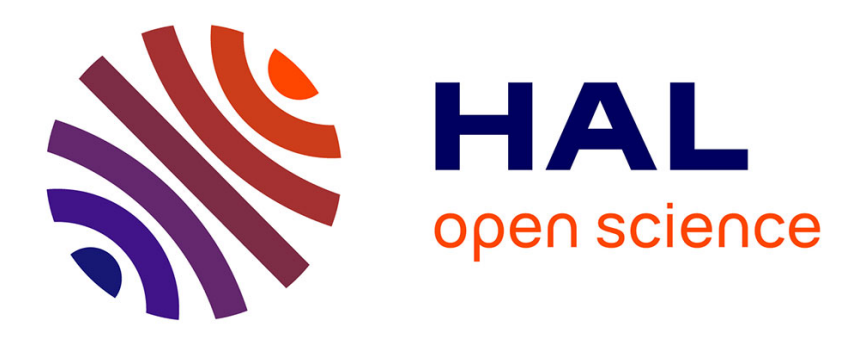

\title{
Mobilizing Europe in national competition: The case of the French Front national
}

Emmanuelle Reungoat

\section{To cite this version:}

Emmanuelle Reungoat. Mobilizing Europe in national competition: The case of the French Front national. International Political Science Review, 2015, 36 (3), pp.296-310. 10.1177/0192512114568816. hal-01825685

\section{HAL Id: hal-01825685 \\ https://hal.umontpellier.fr/hal-01825685}

Submitted on 28 Jun 2018

HAL is a multi-disciplinary open access archive for the deposit and dissemination of scientific research documents, whether they are published or not. The documents may come from teaching and research institutions in France or abroad, or from public or private research centers.
L'archive ouverte pluridisciplinaire HAL, est destinée au dépôt et à la diffusion de documents scientifiques de niveau recherche, publiés ou non, émanant des établissements d'enseignement et de recherche français ou étrangers, des laboratoires publics ou privés. 


\title{
Mobilizing Europe in national competition: The case of the French Front national
}

\author{
Emmanuelle REUNGOAT, Université de Montpellier 1, France
}

Corresponding author: Emmanuelle Reungoat, Département de Science Politique, Université Montpellier 1, 39 Rue de l'Université, 34000 Montpellier, France.

Email : Emmanuelle.Reungoat@univ-montp1.fr

\begin{abstract}
This study of the uses of Europe by the leaders of the Front National shows how the opening of a new European political space can have indirect effects, supporting political parties at the domestic level and strengthening specific actors within political organizations. The theme of Europe, together with European elections and the European Parliament, are transformed by FN leaders into material as well as symbolic resources which they mobilize in the national political space at both inter and intra-party level. These uses of Europe reinforce the capacities and resources of the party as well as its legitimacy and visibility. It helps FN actors to widen their electoral support and allows party presidents to strengthen their position. The article reveals the specificity of the FN relationship to the European arena and underlines the strong continuity of the practices developed by the new leadership. Finally the study provides a detailed account of the process of FN Europeanization and advances understanding of the impact of European integration on domestic political competition.
\end{abstract}

\section{Key words}

Political parties, Europeanization, far right, Euroscepticism, front national, European integration, nationalism, France

There are no funders to report for this submission.

\section{Author biography}

Emmanuelle Reungoat is assistant professor of political science and researcher at the CEPEL at the University Montpellier 1, France. Her research interests are political parties, Europeanization and oppositions to the European integration process. 


\section{Acknowledgements}

The author thanks Marian Sawer, Nicholas Startin and Nathalie Brack for their helpful comments.

\section{Introduction}

The Front National (FN) has progressively made its mark as one of the main opponents to the European Union (EU) in the French and European political space. The way the FN has reclaimed the political arena at the European community level for use as a resource in the national political game sheds light on the evolution of the party and the French political arena. It also serves comparative purposes as a tool for understanding opponents to the EU and the way European integration fits into national political spaces.

The study of the Europeanization of parties and party systems has developed since the 2000s. The first publications focused on the effect of European integration on domestic political cleavages and showed that the direct impact of European integration on party systems remains limited (Mair 2000, 2006; Bartolini 2005). But the literature emphasizes that it is fundamental to study the indirect effects of European integration on the power relations, activities and practices of political parties to understand the recent evolution of national political systems (Ladrech 2005, Mair 2006).

However, so far, research has essentially focused on the indirect impact of the process of European integration on the formal structure of party organizations, in particular on EU specialists within party organizations (Aylott et al. 2007). The European integration process also reinforces the contemporary evolution of political parties (Katz and Mair 1995, 2009) including the progressive marginalization of activists and strengthening of the autonomy of party elites (see for example Raunio 2002), as well as the promotion of new modes of legitimating political decision-making, inherited from the deliberative model of EU institutions (Roger 2009). Over the past decade, another debate has developed which analyses 'euroscepticism' (see Szczerbiak and Taggart 2003, 2008, Mudde 2012). Our knowledge of opponents to the EU has grown but the debate has long been focused on taxonomic concerns and definitional disputes and has offered a weak analytical framework. Unlike preceding work, the emphasis here will be on opposition to Europe as a tool of competition rather than as an attribute (Dakowska 2010).

Hence the article investigates the uses and strategies of appropriation by the $\mathrm{FN}$ of the Europe issue, as well as of the European elections and institutional arena, in national 
competition by partisan actors. Our hypothesis is that, in the French case, this impact of European integration is far from negligible and that it indirectly contributes to structuring the French political landscape today. The European political arena is understood here as a matrix of new political constraints and resources to which national political actors contribute (Coman and Lacroix 2007). The objective of the article goes hand in hand with the need to contextualize the study (Goodin and Tilly 2006) and pay constant attention to both inter- and intra-party competition. The analysis reveals how, in the case of the FN, the European political arena can indirectly constitute an effective base for partisan entrepreneurship and strengthen a specific group within the organization. Thus, it helps us understand how (and under what conditions) the Europeanization of a medium-sized opponent can be a way to sustain its political activity in national competition, therefore contributing to shaping it. The analysis of the FN case raises questions about some aspects of the second-order model (Reif and Schmitt 1980) that seem to have led to downplaying the diversity of national parties' mobilizations for European elections (especially in the case of smaller, medium-sized, and new political parties). It invites us to pay closer attention to those actors to measure more adequately the impact of the Europeanization of national competition.

Numerous studies of the FN have shed light on its history, ideology, and strategy (Declair 1999, Mikenberg and Schain 2003, Dezé 2012), the sociography of its executives (Birnbaum and François, 1996) as well as of its members (Lafont 2005) and voters since the 1980s and more recently (Schields 2007, Mayer 2013). Even so, analysis of the party's relationship with European integration remains neglected to this day. While the FN's stance on the Europe issue has been reviewed (Balent 2012), it remains secondary and the appropriations and uses of the Europe issue and the European political arena by the leadership at the inter- and intra-party level are never a central issue (with the notable exception of Kestel 2008).

The analysis here is based on a methodology combining archival research (press and party archives); interviews with party executives in charge of European issues; discourse analysis based on a systematic quantitative analysis of FN Euromanifestos since 1984; and qualitative analysis of party programs, propaganda material and leaders' media appearances. We draw on various strands of political party analysis to investigate the $\mathrm{FN}$ in terms of strategy and entrepreneurship, but also as a producer of ideology and discourses, as well as ways of thinking and cultural grammars mobilized by activists, sympathizers and voters (Hastings 2001). We also consider it as an organization whose domination is the object of struggles. Thus, we share the approach of scholars who study radical right parties using the 
tools and concepts of political party analysis (Mudde 2010), and who have in recent years called for repositioning European studies within the broader agenda of political sociology (Favell and Guiraudon 2009).

The first section of the article will show that European elections and the European political arena fulfil specific functions in the FN, such as acquiring symbolic as well as material resources which are then turned into domestic political assets, helping the FN to sustain its political activity. The European elections thus appear as a first-order event for FN actors. The second section analyses the evolution of FN discourse on Europe and uses of the criticism of Europe in French national competition. These are also important assets for the organization at the national inter and intra party-level. Additionally, we will address the multiple media discourses on the 'new FN', by examining current developments and continuities in the use of the Europe issue by the FN since Marine Le Pen became the head of the party in January 2011. While limited and specific changes can be pointed out, the analysis shows the great continuity of political practices under the new leadership.

\section{Uses of Europe as a back door for national politics}

Over the past few decades, the European political arena has become a new allocator of resources for political actors. The importance of this phenomenon and thus of European elections for small and medium-sized political parties, particularly in political systems characterized by a strong bipolarization, has probably been somewhat overlooked. In France, small parties are clearly disadvantaged by the two-round majority electoral system, which tends to give the lion's share of seats to mainstream parties and leave little space for newcomers. Access to parliamentary seats is conditional on the ability of party executives to be part of a governing coalition. Unlike other smaller organizations, the FN remains excluded from these. ${ }^{1}$ By contrast, EU elections are more favorable to small and marginal parties, due to the proportional voting system, the fact that voter behaviour tends to benefit nongovernment parties (Reif and Schmitt 1980) and the limited costs and financial risk. This creates a window for the FN, strengthened by the fairly similar pro-European stance of the mainstream parties in France since the 1990s especially. FN actors were able to benefit from this opportunity and obtained between five and eleven MEPs from their first participation in 1984 until 2004, three in 2009 and the exceptional result of 24 MEPs in 2014. This part shows how FN actors were able to convert those mandates and their European activity into symbolic 
and material resources to sustain their political organization and political careers in the domestic arena.

The European Parliament as a provider of symbolic resources

The European political arena - and the European Parliament (EP) in particular - is a source of domestic credibility for the FN. Other political actors, especially those opposed to the European Union, share this conversion of European political activity into a domestic political resource (Brack and Costa 2009). In a national context in which few political functions are within reach, European parliamentary seats are thus presented as external signs of legitimacy. Membership in a group and European partnerships are also sources of political respectability. The European arena appears as a new resource in the old dialectical game played by FN leaders between challenging the rules of the political game and adapting it to fight against stigmatization and gain political credibility (Dezé, 2012). The FN MEP and ex-FN vicepresident Bruno Gollnisch stresses it during an interview:

We have no MPs, not a single senator. But for sure, I have more weight as MEP than for example my friend, R. Boudeau, who is not elected yet but who is responsible of our federation in the Rhône-Alpes region. It gives us legitimacy, it gives us prestige. [...] Obviously, when you organize a public meeting, or when you phone the prefect or when you address newspapers and you are member of a parliament, it's not exactly the same than if you are just somebody somewhere, representing some tiny political group.

When I mention our friendly relationships, our alliances and our co-operation with our friends from Flanders, from Britain, [...] from Bulgaria in the Ataka party, from Austria in the FPÖ, etc. - people are absolutely thrilled, and even more so when they see people in charge, elected representatives. ${ }^{2}$

While it has been difficult for the radical right to form stable coalitions at the European level (Mudde 2007), at every opportunity since the 1980s the FN has actively participated in the creation of parliamentary groups and the development of formal partnerships or of European political parties (Table 1).

Table 1. The position of the FN in the political groups of the European Parliament

\begin{tabular}{|l|l|l|l|l|l|l|}
\hline $1984-1989$ & $1989-1994$ & $1994-1999$ & $1999-2004$ & $2004-2009$ & $2009-2014$ & $2014-2019$ \\
\hline
\end{tabular}




\begin{tabular}{|c|c|c|c|c|c|c|}
\hline & NA & NA & & NA & NA \\
$\begin{array}{c}\text { Technical } \\
\text { Group of } \\
\text { the } \\
\begin{array}{c}\text { European } \\
\text { Right }\end{array}\end{array}$ & $\begin{array}{c}\text { Group of } \\
\text { the } \\
\text { European } \\
\text { Right }\end{array}$ & $\begin{array}{c}\text { Creation of } \\
\text { the } \\
\text { Euronat } \\
\text { Network* }\end{array}$ & $\begin{array}{c}\text { Technical } \\
\text { Group of } \\
\text { Independent } \\
\text { Members, } \\
\text { rejected by } \\
\text { the ECJ }\end{array}$ & $\begin{array}{c}\text { Identity, } \\
\text { Tradition, } \\
\text { Sovereignty } \\
\text { (ITS) } \\
\text { in 2007, } \\
\text { and then } \\
\text { NA }\end{array}$ & $\begin{array}{c}\text { Alliance of } \\
\text { European } \\
\text { Nationalist } \\
\text { Movements } \\
\text { (AENM) }\end{array}$ & $\begin{array}{c}\text { European } \\
\text { Alliance for } \\
\text { Freedom } \\
\text { (EAF) }\end{array}$ \\
& & & & \\
\end{tabular}

*Formal partnerships and European political parties. NA: Non-attached members.

If Euro-parties still hold little weight, a leading position within them can strengthen party executives from small organizations or smaller Member-states, for whom access to international networks remains difficult (Carter et al., 2007). As with other small French parties, FN leaders tried to reach leading positions in their European political groups and/or parties. Those European political functions were then converted into political credit and highlighted at the domestic level. Every time Jean-Marie Le Pen managed to reach the presidency of a parliamentary group this achievement was extensively publicized in the party's national propaganda, as in the 1989 and 1994 Euromanifestos.
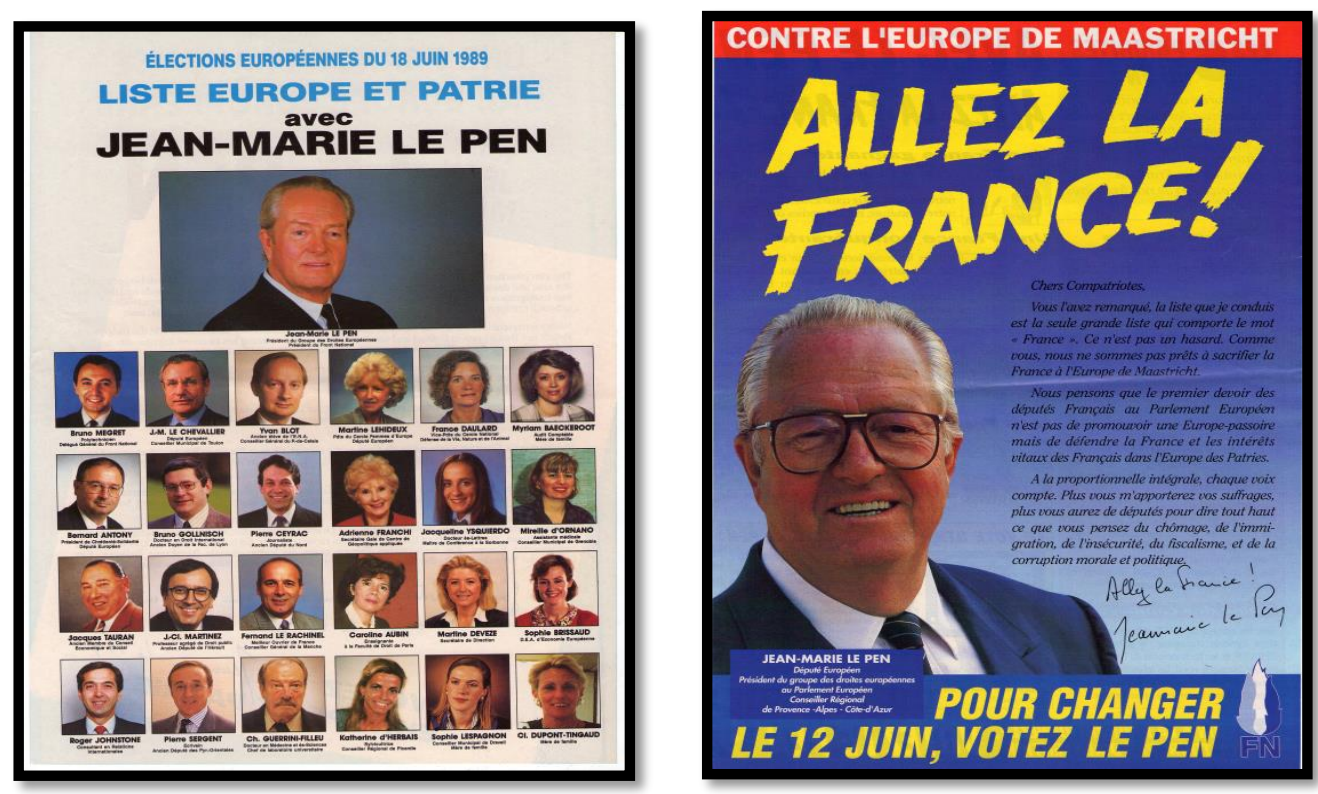

Under J-M Le Pen's pictures, it reads: 'Member of the European parliament, President of the Group of the European Right at the European Parliament, President of the National Front", and in 1994, PACA regional councilor'. 
EU elections and the choice of European partners are also tools in shaping both the party's domestic image, and internal party competition. For the new party leadership it provides an opportunity both to forge alliances for a domestic 'de-demonization' strategy and to assert the new president's leadership on this question at the EU level. Marine Le Pen's speeches at the EP can be watched on the FN's website and Facebook page, as well as on her personal website, Facebook and twitter accounts. She thus appears as a political leader of European stature. This gives her legitimacy inside and outside the party. The promotion of these partnerships is also a way of providing an image of international credibility to counterbalance the FN's national isolation. ${ }^{3}$ Similarly, she denounced the 'old' alliances of the $\mathrm{AENM}^{4}$ chaired by Gollnish, and made new ones, thereby depriving her former opponent in the internal election for the FN presidency in 2011 of the political resource of his strong ties in European networks. Since Autumn 2011, Marine le Pen has chosen to emphasize her personal membership in the European Alliance for Freedom (EAF), in which she serves as vicepresident. Founded in 2010, the EAF includes outwardly more moderate European partners: members of Partij Voor de Vrijheid, of Vlaams Belang, of the Lega Nord and of the FPÖ. Ludovic de Danne, the party's European affairs advisor claims the FN now forms alliances with 'parties that aren't into caricature and folklore [...] with serious people who have participated in governments'. ${ }^{5}$

The FN seems to have taken a new step, beyond 'technical' alliances, in the development of a transnational collaboration for the European elections. Yet the rationale behind this is steeped in traditional party practices. The two-level-game played by Marine Le Pen between the EU and the domestic arena has long been engaged in by FN leaders as well as by other right or radical right parties (Mudde, 2007, Dakowska 2010). The European arena is used to present a changed image that fits within broader party strategies - in the FN's case, gaining respectability at the national level. The new leadership's approach also makes sense in light of inter-party competition. An important concern was to present meaningful alliances with direct competition from the sovereigntist party of Nicolas Dupont-Aignan, who strongly underscores his European partnerships, especially with UKIP.

\section{The European Parliament as a provider of material resources}

In contrast to domestic systems in which mandates remain hard to win for newcomers or outsider parties, the European arena can provide both seats and financial resources. In this way, the Europeanization of FN actors helps the organization to sustain its domestic political 
activity. The material resources provided by the EP supply the party with the financial means to employ executives and staff able to devote themselves exclusively to political activity at the national and European levels. Gollnisch remembers here the impact of the 1984 European election on the party, when FN actors entered the EP:

It was a tremendous asset internally. Because, all at once [...] we got ten people elected. People like J-P. Stirbois who was general secretary of the party, or J.M. Le Chevalier who was more or less treasurer [...] who was J-M Le Pen's director of Cabinet, found themselves with an income! It can seem silly but it enabled them to be absolutely available on a full-time basis.

For the FN as for others such as the French Greens (Shemer-Kuntz 2013), the European arena is a 'back door' into national politics. This is even more the case for the FN: as the FN has no electoral coalition partners in the French majoritarian electoral system, the EP has played a key role in the professionalization of party executives (Kestel 2008). To use Max Weber's phrase, the parliamentary allowance lets them live off and for politics. As a result, Aylott et al's hypothesis is turned on its head (Aylott et al 2007): the specialization on European issues does not result in leading positions within the party, but rather, because they hold leadership positions, FN executives develop skills on European issues. The overrepresentation of MEPs in the FN leadership is striking compared to mainstream or other outsider parties. Since the early nineties, the 'inner logic of the constitution of European lists [...] is quite an intuitive and natural rule' (Gollnisch). Priority was given to FN leaders and top executives during successive terms. Since 1984, FN presidents have been MEPs, as have general delegates (from the creation of the function in 1988 to its suppression in 2007), general secretaries until 2004 and vice-presidents since the renewal of the function in 2007. The opening of the European arena has been one of the conditions allowing the FN to remain in the running at the domestic level and favouring the development of the organization. Since May 2014, seven of the nine members of the FN executive office have been MEPs (table 2).

Table 2: MEPs in FN's highest offices

\begin{tabular}{|l|l|l|}
\hline $\begin{array}{c}\text { European } \\
\text { Parliament } \\
\text { terms }\end{array}$ & $\begin{array}{c}|c| \\
\text { MEPs } \\
\text { in party leadership }\end{array}$ & \multicolumn{1}{|c|}{$\begin{array}{c}\text { MEPs who also hold major responsibilities in } \\
\text { party structure }\end{array}$} \\
\hline $\mathbf{1 9 8 4 - 1 9 8 9}$ & 6 [of 10] & $\begin{array}{l}\text { Party president, vice-president, general secretary and } \\
\text { Jean-Marie Le Pen's Chief of Staff }\end{array}$ \\
\hline $\mathbf{1 9 8 9 - 1 9 9 4}$ & 7 [of 10$]$ & Party president and general delegate \\
\hline $\mathbf{1 9 9 4 - 1 9 9 9}$ & 11 [of 11] & $\begin{array}{l}\text { Party president, vice-president, successive general } \\
\text { secretaries and general delegate }\end{array}$ \\
\hline $\mathbf{1 9 9 9 - 2 0 0 4}$ & 4 [of 5] & Party president, vice-president, general secretary and \\
\hline
\end{tabular}




\begin{tabular}{|l|l|l|}
\hline & & general delegate \\
\hline $\mathbf{2 0 0 4 - 2 0 0 9}$ & 7 [of 7$]$ & $\begin{array}{l}\text { Party president, vice-president, general secretary and } \\
\text { general delegate }\end{array}$ \\
\hline $\mathbf{2 0 0 9 - 2 0 1 4}$ & 3 [of 3] & Party president and the two vice-presidents \\
\hline $\mathbf{2 0 1 4 - 2 0 1 9}$ & 15 [of 24] & $\begin{array}{l}\text { Party president, honorary president, 3 vice-presidents } \\
\text { (among 4), general \& vice general secretaries }\end{array}$ \\
\hline
\end{tabular}

Also important for the FN are the material resources offered by the EP to individual MEPs or related to parliamentary group membership. EP funding is used to hire staff at the EU and local levels, but also non-elected leaders. This is a long-standing practice (Kestel 2008). During the 2009-2014 term, three FN vice-presidents can be found among local MEPs assistants in a period of financial crisis for the party and five among the nine members of the FN Executive office were MEPs or MEPs assistants. Therefore, EP funding contributes to the development of the party as a whole and is partly used to support its national activities. Ludovic de Danne, ex-parliamentary assistant and current European affairs advisor, acknowledges it slightly during the interview.

When I interviewed G. Berthu [French MEP of the Movement for France], he told me that having MEPs assistants working both on European issues and for the party was a common practice. I can imagine that it is the same in the $F N$ ?

Yes, a little bit. Because as I told you, we were a millionaire party in terms of votes but very poor in terms of financial means. Honestly, we were almost like isolated warriors. ${ }^{7}$

The European election as a resource for internal control by the leadership

To conclude this section it is worth noting that the European election can also be used by the leadership as a resource for internal control over the organization. At the intra-party level, the opportunity of gaining a parliamentary seat, as well as the allowance and career path that come with it, creates heated internal competition. While a formal nominating committee does exist, the highly vertical structure of the organization gives the president authority over European electoral nominations. Gollnisch confirms this during an interview:

In theory, we have a nominating committee [...] But [J-M] Le Pen kept the European [nominations] for himself. The nominating committee is actually quite futile because for many people, it was difficult to imagine them taking a stand against the president of the movement.

Thus, for a long time, European elections have been an important opportunity both to discipline and/or reward executives, but also to keep a lid on personal ambitions and drive potential challengers away. This was already the case in 1998, when the choice of who would 
lead the FN list for the 1999 European elections resulted in a standoff between Jean-Marie Le Pen and the party delegate general Bruno Mégret, who was challenging the leader over control of the party apparatus. Then president Le Pen, who was threatened with ineligibility but refused to stand down, planned on nominating his wife rather than his challenger. While it led to the biggest split in the history of the party, as Mégret and more than a hundred executives left the FN, the clash ultimately reinforced Le Pen's authority.

The scenario of the 2009 election reads as a remake of that episode. As the top nominations were seen as crucial in securing control of the party apparatus before the internal election to succeed Jean-Marie Le Pen as party president, the rivalry between Marine Le Pen and her entourage and the 'historic' executives and supporters of Gollnisch grew more heated. Top positions on several lists (Ile de France, Northwest, Southwest) were filled by Marine Le Pen and her entourage, leading to the resignation of two long-time party executives (Carl Lang and Jean-Claude Martinez, who had declared his candidacy for the party's presidency). The internal management of the 2009 European elections and in 2014, the presence of three new candidates among the eight heads of list (Aymeric Chauprayde, Bernard Monot and Gilles Lebreton) who belong to the personal circle of Marine Le Pen and of whom the last, is not even a FN member (member of the RBM-Siel) exemplifies the direct continuity with past uses of this election in the struggle for control of the party apparatus.

\section{Uses and continuity of FN discourse on Europe}

This section explores the FN discourses and programs to show that the Europeanization of FN practices serves the its political enterprise in domestic competition in different ways. The comparison reveals the global continuity with long-standing FN practices in the mobilization of the Europe theme by the new leadership. Europe and European elections are (increasingly) used as tools to distinguish the party from its competitors. The analysis of the party's doctrine and of the evolution of its discourse on Europe indeed confirms that the party's European stance must be understood in relation to the national party system. But it also performs a cohesion-building function at the intra-party level.

\section{Continuity and evolution of FN discourse on Europe}

Like many other West European radical right parties (Mudde 2007), the FN moved from pro-integrationist nationalism to increasingly structured opposition to the EU in the late 1980s. A close scrutiny of party literature (programs and manifestos) reveals the continuity of 
the European doctrine defended by the new leadership. Since the 1990s, the FN's position on Europe is underpinned both by the promotion of the nation, anchored in a traditionalist view and opposed to any form of supra-nationalism, and by the rejection of immigration. The FN was already a staunch advocate of national sovereignty at the time of the ratification of the Maastricht Treaty. By the mid 1990s, the FN's opposition to integration was tied to a perception of politics increasingly informed by identity concerns. The FN's theses were close to those of two think tanks, GRECE and part of the Nouvelle droite, which protect national identity. Thus, opposition to integration fits in with the development of the broader 'neither right nor left' doctrine of the party and its criticism of loss of control over national borders.

The new leadership's critique of the EU rests on several long-standing party concerns. The main themes of Marine Le Pen's 2012 presidential program and of the 2014 platform for the European elections show a strong continuity with these concerns. The criticism of the Euro, the defence of French values, identity and traditions, the protection of French agriculture and public services, but also border control (illustrated in the picture ${ }^{8}$ ) and the restoration of the supremacy of national law over European law have been defended by the FN, sometimes since the 1990s.

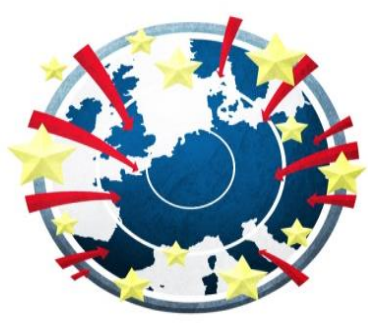

Two developments in the party's discourse on the EU should be mentioned. First, while it remains critical, the FN's stance on Europe has become more Europeanized. The Europe question has featured increasingly prominently in the party literature over the past decade. Lexicometric analysis of Euromanifestos shows that while all parties assigned more space to EU-related themes in their programs beginning in the late 1990s, the most dramatic increase observed is for the FN (Figure 1) - between 1989 and 1999 around 30\% to 36\% of FN Euromanifestos specifically discussed European issues, in 2004 the proportion reached more than $47 \%$ and by 2009 it had reached 67\% (Reungoat 2012ab). Progressively, especially since the 2000s, the party's documents have also contained more and more detailed proposals on how to 'change Europe'.

Figure 1: Global proportion of FN Discourse on European issues at European elections (in \% of the Euromanifestos) 


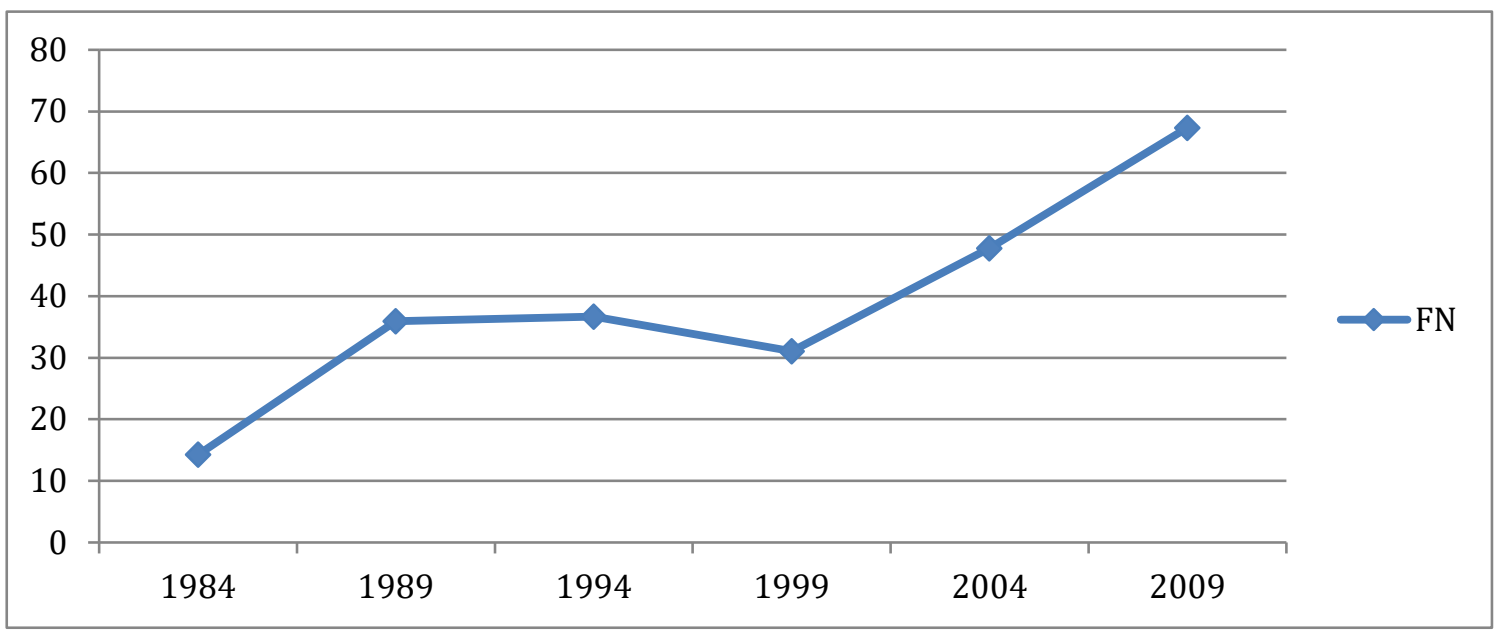

Second, after 2010, as the financial and economic crisis hit Member States and the new leadership made its mark, the discourse of FN leaders on Europe became tougher particularly in the media appearances of the current president and her entourage. The choice of more aggressive words radicalised the party's image. Criticisms of the Euro have been part of FN doctrine since the middle of the nineties but 'exit' from the Euro is now regularly called for and part of the FN's official agenda. Marine Le Pen initially used this discourse during her internal campaign for the party leadership. As the FN candidate for the French presidency she then ostensibly took a very firm stance on Europe and emphasized the need to 'take France out of the Eurozone' in order to 'recover our monetary sovereignty'. The party's vicepresidents echoed her words. Florian Philippot called for 'a concerted end to the Euro'. ${ }^{10}$ This argument was often repeated during the 2012 presidential campaign, as well as the 2014 European one. In March 2013, the proposal came with a new demand. In the wake of the Italian elections, in which candidates who criticized the EU garnered high scores, Marine Le Pen 'solemnly [asked] the President of the Republic to organize a referendum on France's exit from the European Union'. This demand was reiterated in the following months by the most prominent FN leaders ${ }^{11}$. It was however toned down during the 2014 European election campaign.

Understanding the mobilization of FN anti-EU discourses

To understand the current radicalization of the FN discourse on Europe and the detailed proposals to exit the Eurozone, it must be put in historical perspective. We know that EU-related issues is framed in the domestic political spaces (Taggart and Szczerbiak 2008, 
Neumayer 2008, Harmsen and Schild 2011, Conti 2014). That is why parties' stances on Europe are evolutionary processes and must be seen in relation to the patterns of national competition in order to be understood. The increasingly central place of Europe in the FN's discourse is part of a strategy of demarcation from mainstream parties. More precisely, the study of the discourses of French political parties since 1992 confirms this fact and shows a dual trend (Reungoat 2012a).

First, after 1999, and definitively after the 2004 election, the way opponents to the EU both on the right and left of the political spectrum, including the FN, presented their European stance changed progressively. They no longer emphasized that they were against Europe, but claimed they were for another Europe, and presented themselves as promoters of alternative European projects. This also applied to other European parties (Mudde, 2007: 165). This trend extended to French mainstream parties in the second half of the 2000s, particularly in the wake of the rejection of the Constitutional Treaty and then in the context of the economic crisis. By the end of the decade, calls for 'another Europe' were made across the entire political spectrum. Flirtation of French mainstream parties with 'euroscepticism' was particularly visible in the 2009 and 2012 elections (Rozenberg 2011, Vassallo 2012).

Faced with majority parties that present themselves as torchbearers of change and of an alternative Europe, interparty competition has pressured anti-EU parties to toughen their discourse in order to retain the resource of distinctiveness. This evolution illustrates the 'incitation effect' described by Robert Harmsen (Harmsen 2007: 84-85). Similar developments can be observed in various Member states from eastern and central Europe at the beginning of the 2000s, (Neumayer 2003, Szczerbiak, 2008, Dakowska 2010). The radicalisation of the FN leadership's discourse on the EU and the Euro is the result of continuity in the party's discursive practices, as it fulfils the same functions as former stances on Europe.

The new FN leadership also continued the party's strategy of dominating the political space of opposition to European integration. Since the early 1990s, FN executives have strived to define the party as the 'true voice' of opposition to the EU to fend off many competing anti-EU endeavours from single-issue parties or partisan factions. They have teamed up with individuals whose political credit could prove useful. In 1999, General de Gaulle's grandson, Charles de Gaulle, was second on the list for the European elections, after Jean-Marie Le Pen. The Gaullist legacy of defence of French national sovereignty is indeed a shared reference worth competing over (see also Startin 2014), as it brings significant legitimacy in the circles of the anti-EU right. More recently, the radicalisation of the leader of 
the small sovereigntist and Gaullist party Stand up Republic! Dupont-Aignan, served as a trigger, pushing the FN to follow suit. In November 2010, upon announcing his candidacy for president, he tore up a giant fake ten-Euro note, which then featured in his campaign posters and launched a campaign calling for France's exit from the Eurozone. Beyond the use of more aggressive words against the European construction, the FN has collaborated with the party 'Souveraineté, Indépendance et libertés' (SIEL), founded in January 2012 by a figure of French sovereigntism, Paul-Marie Couteaux to attract sovereigntist activists and Gaullist voters in the 2012 and 2014 elections.

\section{The cohesion-building function of radicalism at intra-party level}

While the strategic dimension of political stances has often been rightly pointed out, it has all too often been perceived as the dominant motive of critical opposition to the EU. This leads one to overlook constraints relating to intra-party struggles and cultures. In addition to appearing to voters as a salient feature in domestic competition, the party's radical critique of the EU also constitutes a valuable resource at the intra-party level. This is meaningful for grassroots members. Radicalism fulfils a cohesion-building function. In the FN's case, the drastic calls to exit the Eurozone and sometimes the EU itself since 2010-2011 have had two main benefits. First, they served as a resource for Marine Le Pen in the fight to secure the party's leadership. Accused of defending an excessively moderate line, the campaigning vicepresident displayed her ability to 'talk tough' as early as 2010, thus ensuring the continuity of her father's style. We know that, along with the party's iconography, symbols and celebrations, this specific discursive style helps the FN construct a social space with distinctive reference points, a cultural universe that is at odds with the dominant codes.

The FN's discourse on the EU must therefore also be understood in light of the efforts to sustain its role as 'producer of meaning' over the long term. The FN is indeed a political organization that produces collective references in terms of culture and identity. FN activists often refer to the party as a 'family' and see it as a refuge and a very important space of sociability. In smaller parties that cultivate a culture of radicalism and differentiation, ideology plays a symbolic but central role in ensuring party cohesion. The specific radicalism of its political discourse constitutes a central element of the FN's identity which ensures the recruitment and the loyalty of activists and executives. Hence, the tougher stance taken in comparison to other parties critical of the EU is also a way to 'stick' to this radical culture. While it remains a secondary concern, the opposition to European integration seems to have 
become more central in the FN's doctrinal landscape, and by extension in the party's identity construction over the past decade. The singularity of FN voters and sympathizers and their cohesion around a highly hostile attitude toward European integration has been confirmed from the early 2000s on (Ysmal 2000, Belot et al. 2013, Gómez-Reino and Llamazares 2013). Like other parties in Europe and France (such as the 'Front de gauche' or The Greens who became 'Europe Ecology-The Greens' in 2010) this use of Europe as a source of internal cohesion, illustrates how European integration can contribute to restructuring collective political identity in different ways. This is in contrast with the situation in certain mainstream parties especially, where the Europe issue appears to be a possible factor in dilution of party identity over recent decades (Roger 2009; 283).

\section{Conclusion}

The analysis of the way party actors deal with Europe helps bring to light their day-today party practices as well as the contemporary evolution of political parties. In the FN case, the ability of party actors to develop various 'uses' of 'Europe' has contributed to sustain and develop the party in the domestic competition for thirty years and has buttressed, internally, the domination, first, of Jean-Marie Le Pen, and then of his daughter and her entourage. Despite a few changes (in the communication of EU issues and new European alliances), the new leadership's attitude toward Europe reflects a globally unchanged approach. There is continuity as well in the uses of the European arena, the alliances forged at the EU level and the European elections, all of which were already observable in the FN of the 1990s and 2000s. The analysis here is a modest contribution to rising scientific questioning about the transition of the FN since 2011 and the potential change it could induce (Crepon and al., forthcoming).

The European integration process thus contributes to shaping the political game at the inter- and intra-party level and also the practices of party actors. For comparative purposes, our findings show that the degree of openness/closure of domestic competition to outsiders, the party's position within it and its relationships with majority parties are significant. Party doctrine, identity references and the specific feature of its structure are also determinants that play an important part in shaping the 'uses' of the European political arena by party actors. The specific mobilization of the Europe issue and arena by the FN is the result of its exclusion 
from MP positions because of the French institutional framework and voting system, but also of the impossibility, imposed by rival parties, of entering governing coalitions. In other words, the FN could be compared to other radical parties as well as to small or medium-sized political organizations, in outsider positions in the domestic competition, who all share a specific interest in mobilizing 'Europe'.

This analysis reveals a constitutive weakness of the second-order election model. The latter considers European elections to be political events where there is 'less at stake' and hence low levels of commitment from political parties. But this model leaves the practices of smaller, medium-sized and new political parties in a grey area and although Reif and Schmitt (1980) mentioned that these parties could expect 'brighter prospects', subsequent analyses have tended to neglect the importance of actors' perceptions of European elections. Unlike governmental parties, European elections appear as first-order events for some outsider parties because they provide a unique opportunity to gain seats as well as symbolic and material political resources. This is also the case in France for the Greens and parties from the European United Left (GUE/NGL). Finally, this article helps showing the indirect effects of the development of a European political space on national competition. This supranational arena can contribute to the survival of parties, and consequently to pluralism by helping, against contemporary trends of de-politicization of domestic political competition (Katz and Mair 1995, 2009), to maintain and strengthen political conflicts within national party systems.

\section{References}

Aylott, Nicholas, Elisabeth Carter, Robert Ladrech, Richard Luther K., Thomas Poguntke (2007) The Europeanization of National Political Parties. Londres: Routledge.

Bartolini, Stefano (2005) Restructuring Europe. Oxford: OUP.

Balent, Magalie (2012) Le Monde selon Marine. Armand-colin.

Belot, Céline, Bruno Cautrès and Sylvie Strudel (2013) L'Europe comme enjeu clivant. Revue française de science politique 63(6) : 1081-1112.

Birenbaum, Guy and Bastien François (1996) Unité et diversité des dirigeants frontistes, in Nonna Mayer and Pascal Perrineau, Le Front national à découvert. Presses de Sciences Po, 83-106.

Brack, Nathalie and Olivier Costa (2009) What Role for the Eurosceptic MEPs, Dieter Fuch et al., Euroscepticism. Opladen: Barbara Budrich Publishers, 253-272.

Carter, Elizabeth, Kurt Luther, Thomas Pogunkte (2007) European integration and internal party dynamics, in Nicholas Aylott et al. The Europeanization of National Political Parties. Routledge, 127.

Crepon, Sylvain, Alexandre Dezé, Nonna Mayer, (2015 forthcoming), Le front national: un parti en transition?. Presses de Science po.

Coman, Ramona, Justine Lacroix (éd.) (2007) Les résistances à l’Europe. Éditions de l'ULB.

Conti, Nicolo (2014) Party attitudes towards the EU in the member states. Routledge.

Dakowska, Dorota (2010) Whither Euroscepticism? The Uses of European Integration by Polish Conservative and Radical Parties. Perspectives on European Politics and Society, 11(3): 254-272. 
Declair, Edward G. (1999) Politics on the Fringe. Durham, London: Duke University Press.

Dezé, Alexandre (2004) Between Adaptation, Differentiation and Distinction : Extreme Right Parties within Democratic Political Systems, Cas Mudde, Roger Eatwell, Western Democracies and the New Extreme Right Challenge. London: Routledge, 119-140.

Dezé, Alexandre (2012) Le Front national : à la conquête du pouvoir ?. Paris : Armand Colin.

Favell, Adrian, Virginie Guiraudon (2011) Sociology of the European Union. Palgrave Macmillan.

Goodin, Robert E, Charles Tilly (2006) The Oxford Handbook of Contextual Political Analysis. Oxford University Press.

Gomez-Reino, Marge and Ivan Llamazares (2013) The Populist Radical Right and European Integration: A Comparative Analysis of Party-Voter Links. West European Politics 36(4): 789-816.

Harmsen, Robert (2007) Is British Euroscepticsm still unique?, in Justine Lacroix. et Ramona Coman, Les Résistances à l'Europe. Edition de l'ULB, 69-72.

Harmsen, Robert and Joachim Schild (2011) Debating Europe. Baden-Baden: Nomos.

Hastings, Michel (2001), Partis politiques et administration du sens, Dominique Andolfatto, Fabienne Greffet, Laurent Olivier, Les Partis politiques, quelle perspective?. Paris: L'Harmattan, 22-23.

Katz, Richard and Peter Mair (1995) Changing Models of Party Organization and Party Democracy: the Emergence of the Cartel Party. Party Politics 1(1): 5-28.

Katz, Richard and Peter Mair (2009) The Cartel Party Thesis: A Restatement. Perspectives on Politics 7(4) : 753-766.

Kestel, Laurent (2008) Le Front National et le parlement européen, in Neumayer et al., L'Europe contestée. Paris: Michel Houdiard, 210-232.

Lafont, Valérie (2005) A Two-centuries-old Galaxy, Bert Klandermans and Nonna Mayer, Extreme Right Activists in Europe. Londres: Routledge, 93-126.

Ladrech, Robert (2005) The Europeanization of interest groups and political parties, in Simon Bulmer and Christian Lequesne, The Member States of the European Union. Oxford University Press, 317 337.

Mair, Peter (2000) Limited impact of Europe on national party systems. West European Politics 23(4): 27-51.

Mair, Peter (2006) Political Parties and Party systems, Paolo R. Graziano, Maarten P. Vink, Europeanization: New research agendas. Basingstokes: Palgrave Macmillan, 154-166.

Mayer, Nonna (2013) From Jean-Marie to Marine Le Pen: Electoral Change on the Far Right. Parliamentary Affairs, 66(1): 160-178.

Minkenberg Michael and Martin A. Schain (2003) The Front National in Context: French and European Dimensions, Peter Merkl, Leonard Weinberg, Right-Wing Extremism in the Twenty-First Century. Franck Cass.

Mudde, Cas (2007) Populist Radical Right Parties in Europe. Cambridge University Press.

Mudde, Cas (2010) The Populist Radical Right: A Pathological Normalcy. West European Politics, 33: $1167-86$.

Mudde, Cas (2012) The comparative study of party-based Euroscepticism. East European Politics 28(2): 193-202.

Neumayer, Laure (2003) L'européanisation indirecte des pays candidats à l'adhésion à l'Union européenne. Politique européenne 10(2), 121-147.

Neumayer, Laure (2006) L'enjeu européen dans les transformations post-communistes 1989-2004. Belin.

Neumayer, Laure (2008) Euroscepticism as a Political Label: the Use of European Union Issues in Political Competitions in the New Member States. European Journal of Political Research, 47(2): 135-160.

Raunio, Tapio, (2002) Why European Integration Increases Leadership Autonomy within Political Parties. Party Politics 8(4): 405-22.

Reif, Karlheinz and Hermann Schmitt (1980) Nine Second-Order National Elections: A conceptual Framework for the analysis of European election Results. European Journal of Political Research, 8(1): 3-44.

Reungoat, Emmanuelle (2012a) Changes in discourse and resistance positions toward Europe in French Political Parties (1979-2009), Daniele Pasquinucci and Daniela Preda, Consensus and European Integration. Peter Lang, 165-180. 
Reungoat, Emmanuelle (2012b) Résister c'est exister ? Comprendre la construction des résistances à l'intégration européenne au sein des partis politiques français (1979-2009), thèse de science politique, Université Paris 1 Sorbonne.

Roger, Antoine (2009) The impact of European policies on national political parties: a theoretical outlook. Dieter Fuchs, Raul Magni-Berton and Antoine Roger Euroscepticism. Opladen: Barbara Budrich Publishers, 273-290.

Rozenberg, Olivier (2011) Playing softly with euroscepticism: the 2009 European elections in France. In Robert Harmsen and Joachim Schild Debating Europe. Baden-Baden: Nomos, 51-68.

Shemer-Kunz, Yoav (2013) European elections as a 'Back Door' to National Politics: The Case of the French Greens in 2009, Ben Crum and John E. Fossum, Practices of Inter-Parliamentary Coordination in International politics. ECPR Press, 161-174.

Shields, Jim (2007) The Extreme Right in France. From Pétain to Le Pen. London \& New York.

Startin, Nicholas (2014) Contrasting Fortunes, Differing Futures? The Rise (and Fall) of the Front National and the British National Party. Modern \& Contemporary France, 22:3, 277-299.

Szczerbiak, Aleks (2008) Opposing Europe or problematizing Europe? Euroscepticism and 'Eurorealism' in the Polish party system, Paul Taggart and Aleks Szczerbiak, Opposing Europe. Oxford University Press, Vol. 2, 221-242.

Taggart, Paul and Aleks Szczerbiak (2003) Theorising Party-Based Euroscepticism: Problems of Definition, Measurement and Causality. SEI Working Paper No. 69.

Taggart, Paul and Aleks Szczerbiak (ed.) (2008) Opposing Europe: the comparative Party Politics of Euroscepticism. Oxford University Press, Vols 1 and 2.

Vassallo, Francesca (2012) The EU Discourse in the 2012 French Presidential Election. French Politics, Culture and Society, 30(3): 79-95.

Ysmal, Colette (2000) Face à l'extrême droite, la droite existe-telle, in Bréchon Paul, Laurent Annie, Perrineau Pascal, Les Cultures politiques des Français. Presses de Sciences Po, 139-164.

\footnotetext{
${ }^{1}$ Except for the 1986 election where 35 FN MPs were able to enter the National assembly due to a one-shot proportional voting system, and for the election of Yann Piat in 1988 and of Jean-Marie Le Chevalier in 1997 invalidated in 1998, the FN had to wait until 2014 to get two MPs elected.

${ }^{2}$ Interview with Bruno Gollnisch, member of FN executive office since the 1980s, former general delegate and vice-president (1994-2011), MP (1986 -1988) and MEP since 1989, 08/01/2010.

${ }^{3}$ Interview with Catherine Salagnac, ex MEP assistant, member of the FN Political Office 09/01/2010.

${ }^{4}$ A network led by members of the British National Party, of the Hungarian party Jobbik, of the Italian Movimento Sociale - Fiamma Tricolore and of the Bulgarian National Democratic Party.

${ }^{5}$ Ludovic de Danne, Slate.fr, 21/06/2012.

${ }^{6} \mathrm{We}$ consider as part of the party leadership the members of the following internal bodies: the 'Political Office' which is, with about 40 members, more important than the 'Central committee' (the party parliament) but less so than the 'Executive office'. The latter is the seat of the main decision-making functions of the party, held by the president, the honorary president, vice-president(s), general secretary, general delegate, treasurer included in column 3. Data in 1984 and 1989 are estimated figures.

${ }^{7}$ Interview with Ludovic de Danne, MEP assistant since 2004, in charge of relations with political parties in the European parliament, 15/04/2014.

${ }^{8}$ FN 2014 European election website.

${ }^{9}$ Those figures and the graph are based on a quantitative content analysis of FN and French political parties Euromanifestos, [reference removed] using the Semato lexicographic software. (The segments were manually classified). The "Discourse on European issues" presented here, first comprised the developments exclusively situated at the European scale. A non-exhaustive list of subjects includes: European elections, policies, actors and institutions. The category also includes developments that reflect a preoccupation with French interests regarding Europe. It therefore concerns itself with remarks having to do with national issues when they are related to the evocation of advantages or threats from the EU. It is worth noting that the developments exclusively situated at the European scale also increase for the FN (from 10\% in 1999 to more than 30\% in 2014 and 50\% in 2009). The 'National discourse level', comprised of developments at the domestic scale, does not appear here.

${ }^{10}$ Marine Le Pen, RMC radio, 17/01/2011. Florian Philippot, National Radio 24/07/2012.

${ }^{11}$ Especially Florian Philippot, vice-president since 2012 in France Info and RMC in March 2013, LCI \& BFM TV then France Inter in May 2013.
} 